\title{
LIFAC Sorbent Injection Desulfurization Demonstration Project: A DOE Assessment
}

January 2001

U.S. Department of Energy

National Energy Technology Laboratory

P.O. Box 880, 3610 Collins Ferry Road

Morgantown, WV 26507-0880

and

P.O. Box 10940, 626 Cochrans Mill Road

Pittsburgh, PA 15236-0940

website: $\underline{\text { www.netl.doe.gov }}$

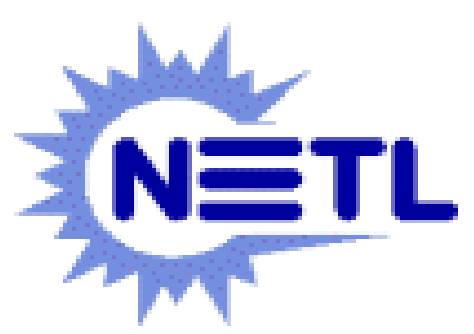




\section{Disclaimer}

This report was prepared as an account of work sponsored by an agency of the United States Government. Neither the United States Government nor any agency thereof, nor any of their employees, makes any warranty, express or implied, or assumes any legal liability or responsibility for the accuracy, completeness, or usefulness of any information, apparatus, product, or process disclosed, or represents that its use would not infringe privately owned rights. Reference therein to any specific commercial product, process, or service by trade name, trademark, manufacturer, or otherwise does not necessarily constitute or imply its endorsement, recommendation, or favoring by the United States Government or any agency thereof. The views and opinions of authors expressed therein do not necessarily state or reflect those of the United States Government or any agency thereof. 


\section{Contents}

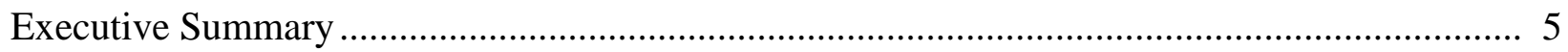

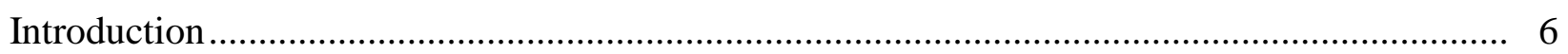

II Technical and Environmental Assessment ……......................................................... 7

II.A Promise of the Technology …………………........................................... 7

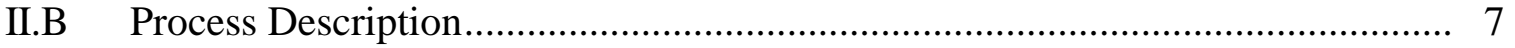

II.C Project Objectives/Results ........................................................................... 9

II.D Environmental Performance …………………............................................. 10

II.E Post-Demonstration Achievements.................................................................... 10

III Operating Capabilities Demonstrated .................................................................... 11

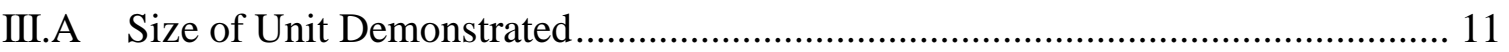

III.B Performance Level Demonstrated....................................................................... 12

III.C Major Operating and Design Variables Studied ................................................... 12

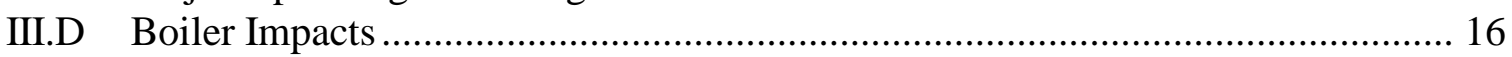

III.E Commercialization of the Technology ............................................................... 16

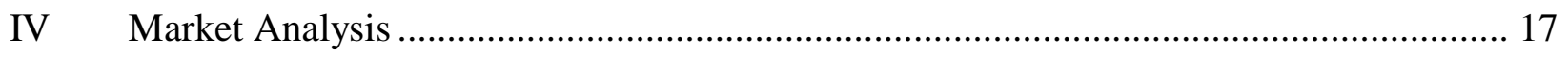

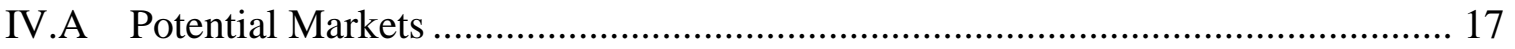

IV.B Economic Assessment ................................................................................. 17

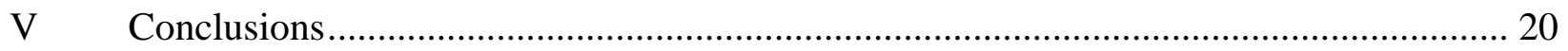

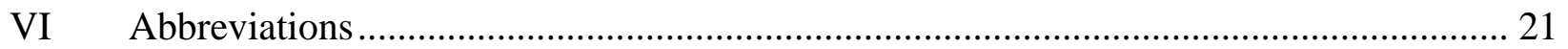

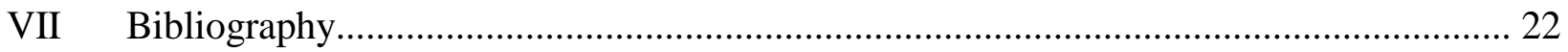




\section{List of Figures and Tables}

Figure

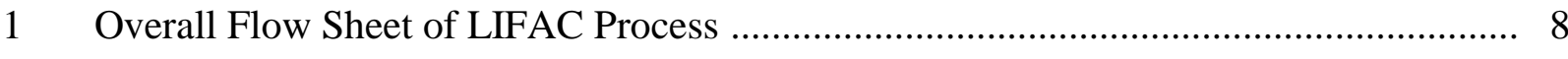

2 Schematic Flow Sheet of LIFAC Process ............................................................ 9

3 Effect of Limestone Grind Size on $\mathrm{SO}_{2}$ Removal .............................................. 13

$4 \quad$ Effect of $\mathrm{Ca} / \mathrm{S}$ Ratio on $\mathrm{SO}_{2}$ Removal ........................................................... 13

5 Effect of Approach-to-Saturation Temperature on $\mathrm{SO}_{2}$ Removal ............................... 14

6 Effect of Ash Recycle Ratio on $\mathrm{SO}_{2}$ Removal .......................................................... 15

$7 \quad$ Effect of Boiler Load on $\mathrm{SO}_{2}$ Removal .......................................................... 15

\section{Table}

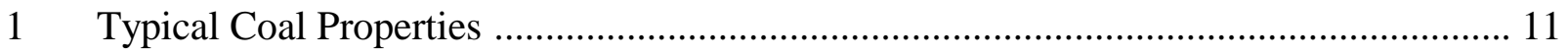

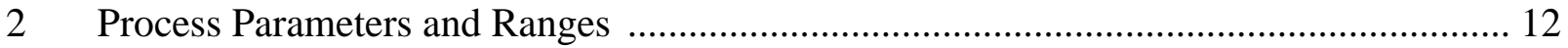

3 LIFAC Demonstration Capital Cost at Richmond Power \& Light .............................. 18

4 Estimated Operating Cost of LIFAC at RP\&L ................................................... 18

5 Estimated Costs for 150 MWe LIFAC System for Commercial Application ................. 19 


\section{Executive Summary}

This document serves as the U.S. Department of Energy (DOE) post-project assessment of the Clean Coal Technology (CCT) Round III project LIFAC Sorbent Injection Desulfurization Demonstration Project. In 1990, LIFAC North America, Inc. entered into cooperative agreement no. DE-FC22-90PC90548 with Richmond Power and Light Company (RP\&L), which provided the host site and served as a cofunder. DOE provided 50 percent of the total project cost of $\$ 21$ million. Other cofunders were ICF Kaiser Engineers, Tampella Power Corporation, Electric Power Research Institute (EPRI), Black Beauty Coal Company, and the State of Indiana. The demonstration was conducted in Richmond, Wayne County, Indiana, at RP\&L's Whitewater Valley Station Unit 2 (a 60-MWe boiler) between September 1992 and June 1994.

The abbreviation LIFAC refers to the process, which involves limestone injected into the furnace with activation of untreated calcium oxide. LIFAC technology is designed to remove sulfur dioxide $\left(\mathrm{SO}_{2}\right)$ produced in a coal-fired utility boiler, using a limestone sorbent at a calcium/sulfur molar ratio of 2.0-2.5/1. A unique feature of this technology is humidification of the flue gas in a separate activation reactor, which increases $\mathrm{SO}_{2}$ removal. An electrostatic precipitator downstream from the point of injection captures the reaction products, along with the fly ash entrained in the flue gas.

The primary objectives of this project were to:

C Achieve a total $\mathrm{SO}_{2}$ removal rate of up to 85 percent.

C Demonstrate successful operation of the LIFAC process in a retrofit application in a power plant burning high sulfur U.S. coals.

C Produce a dry solid waste suitable for disposal in a landfill.

These goals were partially met in this project, which was conducted using medium sulfur coals ranging in sulfur content from 2.0 to 2.8 percent. Coals containing over 3 percent sulfur, which are generally considered high sulfur, were not tested because the unit operation could not be stabilized. However, the LIFAC technology could well be applicable to higher sulfur coals. Overall $\mathrm{SO}_{2}$ removal of about 70 percent was achieved in long term testing; the capability of increasing $\mathrm{SO}_{2}$ removal to 85 percent was inferred from parametric studies but was not actually demonstrated.

LIFAC system availability and mechanical operation were very good, and there were no adverse effects on boiler or auxiliaries. The waste product was a dry, stable solid, which was disposed of in a landfill. LIFAC technology has not been further commercialized. In the United States, compliance with $\mathrm{SO}_{2}$ emissions regulations has been achieved primarily through fuel switching or purchase of emission allowances. If a market develops for flue gas desulfurization (FGD) processes with less $\mathrm{SO}_{2}$ emissions reduction capability than conventional wet scrubbing, LIFAC could potentially find a niche. 


\section{Introduction}

The goal of the U.S. Department of Energy (DOE) Clean Coal Technology (CCT) program is to furnish the energy marketplace with a number of advanced, more efficient, and environmentally responsible coal utilization technologies through demonstration projects. The purpose of these projects is to establish the commercial feasibility of the most promising advanced coal technologies that have developed beyond the proof-of-concept stage.

This document serves as the DOE post-project assessment of the CCT Round III project LIFAC Sorbent Injection Desulfurization Demonstration Project, described in a report to Congress (LIFAC North America, Inc. 1990). LIFAC North America, Inc. entered into a cooperative agreement with DOE to conduct the demonstration in 1990. Richmond Power and Light Company (RP\&L) provided the host site and served as a cofunder. Other cofunders were ICF Kaiser Engineers, Tampella Power Corporation, Electric Power Research Institute (EPRI), Black Beauty Coal Company, and the State of Indiana. DOE provided 50 percent of the total project cost of $\$ 21$ million.

LIFAC North America, Inc. is a partnership of Tampella Power Corporation and ICF Kaiser Engineers. Tampella initiated work on the LIFAC process in Finland in the 1980s in response to increasingly stringent environmental regulations enacted in that country. Tampella's efforts included laboratory and pilot-plant tests, culminating in a full-scale demonstration in Finland in 1986. In 1988, Tampella tested high sulfur U.S. coals in its pilot plant in Finland, demonstrating over 70 percent removal of sulfur dioxide $\left(\mathrm{SO}_{2}\right)$ from the flue gas.

The CCT demonstration was conducted at RP\&L's Whitewater Valley Station Unit 2, a 60-MWe boiler, between September 1992 and June 1994. This report is an independent evaluation, and is based on information from LIFAC's final report (ICF North America 1998) and other listings in the Bibliography. 


\section{Technical and Environmental Assessment}

\section{II.A Promise of the Technology}

The LIFAC process involves limestone injected into the furnace with activation of untreated calcium oxide. This project was undertaken to evaluate the technical and economic feasibility of using the LIFAC technology in a coal-fired utility system to reduce emissions of $\mathrm{SO}_{2}$ by up to 85 percent. This commercial scale demonstration was supported by the results of previous studies and proof-of-concept (POC) tests by LIFAC and its parent company, Tampella. LIFAC is a method of flue gas desulfurization (FGD) that uses a limestone sorbent and removes the waste as a dry solid product in an electrostatic precipitator (ESP). The process involves conventional furnace sorbent injection coupled with a unique, patented activation reactor that converts unreacted sorbent to hydrated lime for increased $\mathrm{SO}_{2}$ removal.

The developers intended to offer a process that was less expensive than wet process FGD systems, which provide higher levels of $\mathrm{SO}_{2}$ removal (>90 percent). Advantages claimed for LIFAC compared with other furnace sorbent injection processes include: (a) higher $\mathrm{SO}_{2}$ removal rates; (b) use of relatively inexpensive limestone as sorbent rather than lime; (c) ease of disposal of dry solid wastes; and (d) the capability of being easily retrofitted into a relatively small space in a typical power plant, enabling installation during a normal scheduled outage.

\section{II.B Process Description}

Finely pulverized limestone $\left(\mathrm{CaCO}_{3}\right)$ is injected into the furnace at a point where temperatures range from 1,800 to $2,000 \mathrm{EF}$, which results in decomposition to lime $(\mathrm{CaO})$, which is more reactive:

$$
\mathrm{CaCO}_{3} \rightarrow \mathrm{CaO}+\mathrm{CO}_{2}
$$

About 25 percent of the $\mathrm{SO}_{2}$ in the flue gas reacts with the lime to form calcium sulfite $\left(\mathrm{CaSO}_{3}\right)$ and calcium sulfate $\left(\mathrm{CaSO}_{4}\right)$ :

$$
\begin{array}{lll}
\mathrm{SO}_{2}+\mathrm{CaO} & \rightarrow & \mathrm{CaSO}_{3} \\
\mathrm{SO}_{2}+\mathrm{CaO}+1 / 2 \mathrm{O}_{2} & \rightarrow & \mathrm{CaSO}_{4}
\end{array}
$$

As a result the $\mathrm{SO}_{2}$ oxidizing, the flue gas also contains a small amount of sulfur trioxide $\left(\mathrm{SO}_{3}\right)$, essentially all of which reacts with lime, yielding additional $\mathrm{CaSO}_{4}$ :

$$
\mathrm{SO}_{3}+\mathrm{CaO} \quad \rightarrow \quad \mathrm{CaSO}_{4}
$$


The flue gas, containing the remaining 75 percent of the $\mathrm{SO}_{2}$ plus unreacted lime, exits the boiler and passes through the furnace air preheater, after which the mixture enters the LIFAC activation reactor. This reactor is an elongated vertical duct equipped with spray nozzles at the top. A water spray humidifies the gas, converting the lime to hydrated lime, $\mathrm{Ca}(\mathrm{OH})_{2}$ :

$$
\mathrm{CaO}+\mathrm{H}_{2} \mathrm{O} \quad \rightarrow \quad \mathrm{Ca}(\mathrm{OH})_{2}
$$

Further $\mathrm{SO}_{2}$ removal occurs through reaction with hydrated lime, yielding additional calcium sulfite:

$$
\mathrm{SO}_{2}+\mathrm{Ca}(\mathrm{OH})_{2} \quad \rightarrow \quad \mathrm{CaSO}_{3}+\mathrm{H}_{2} \mathrm{O}
$$

The flue gas leaving the activation reactor enters the existing ESP, where the spent sorbent and fly ash are removed. A portion of the solids is recycled to the activation reactor and the remainder is sent to a landfill for disposal. Figures 1 and 2 are schematic flow sheets of the LIFAC process.

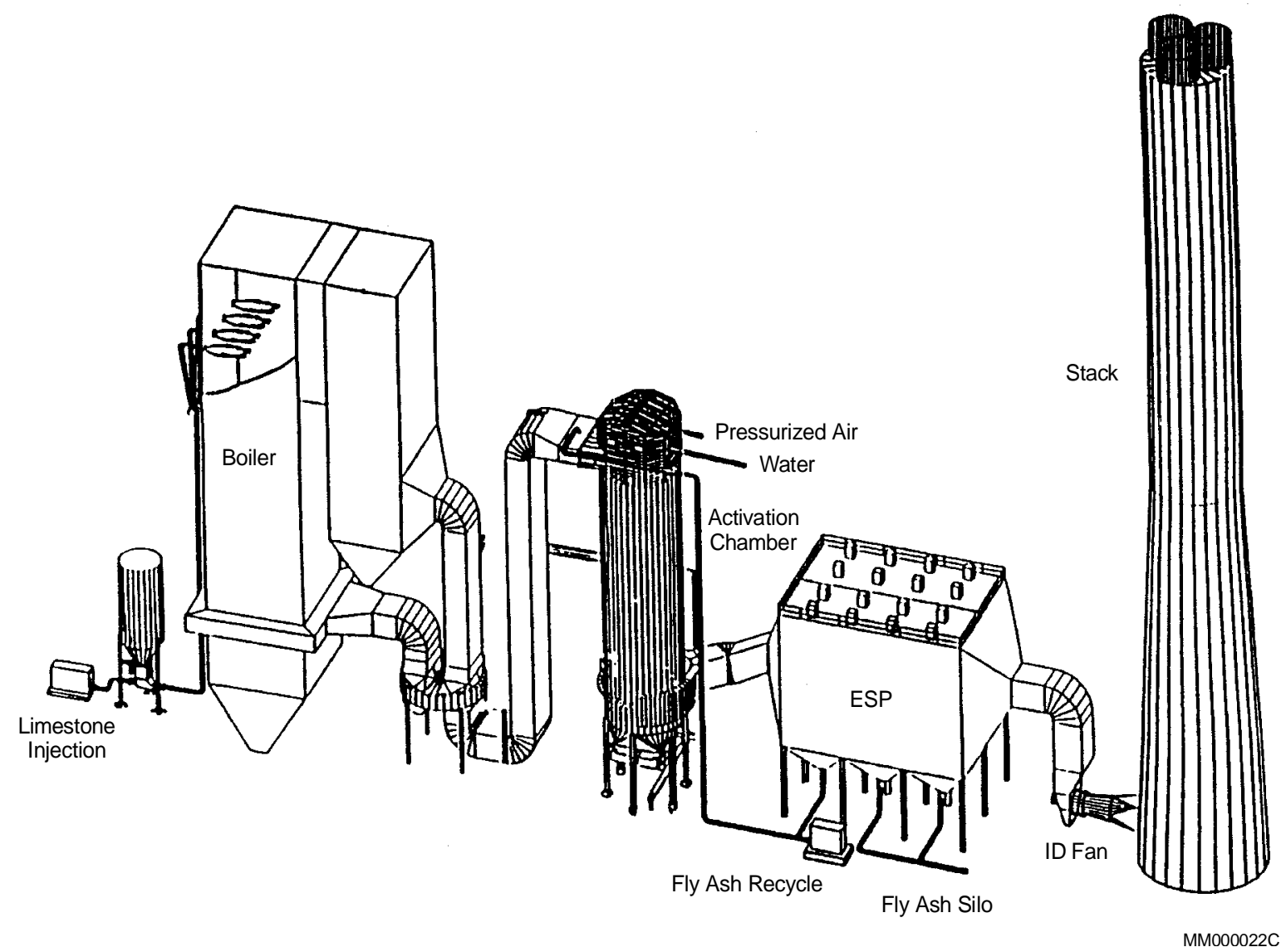

Figure 1. Overall Flow Sheet of LIFAC Process 


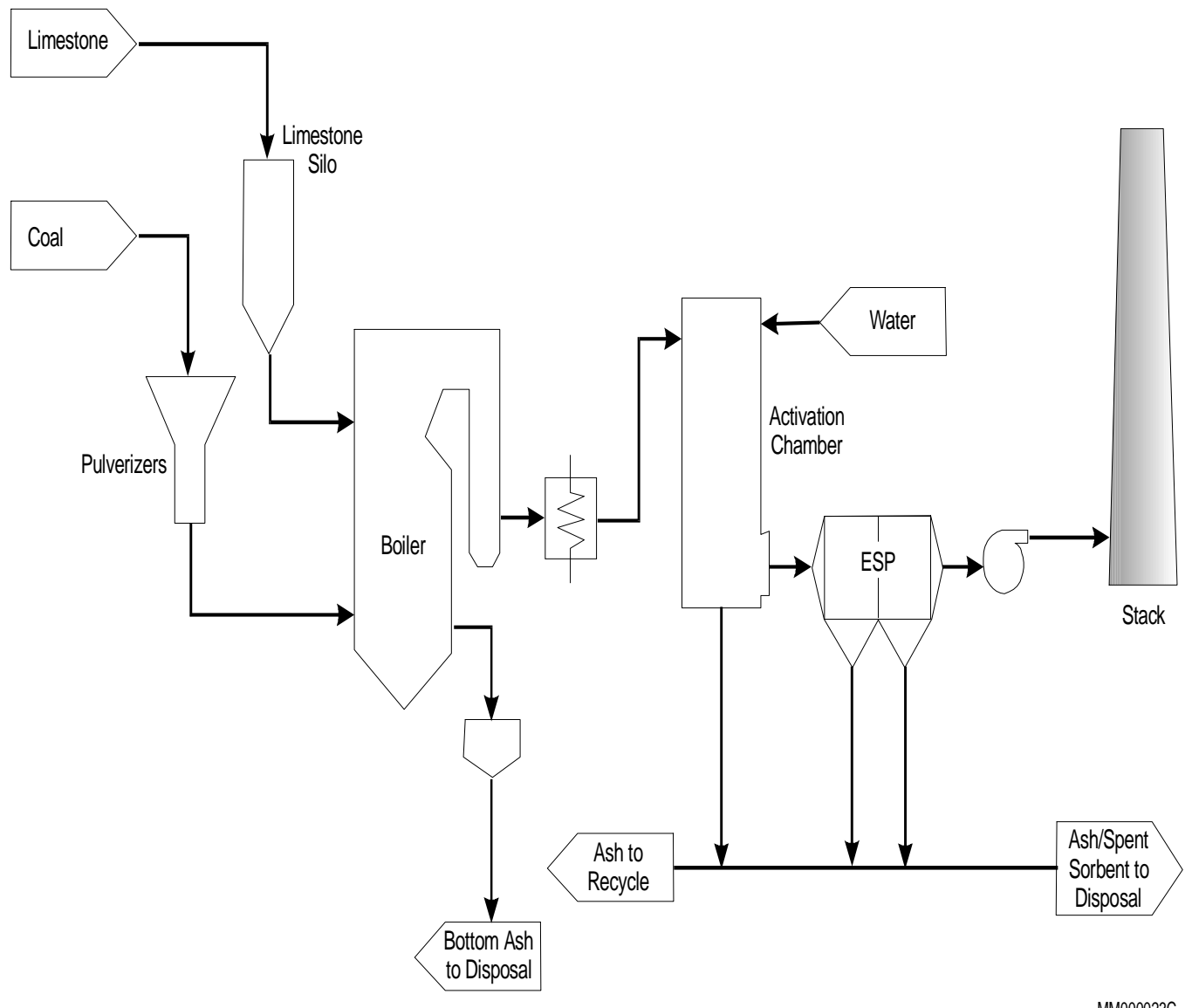

Figure 2. Schematic Flow Sheet of LIFAC Process

\section{II.C Project Objectives/Results}

The primary objectives of this project were to:

C Achieve an $\mathrm{SO}_{2}$ removal rate of up to 85 percent.

C Demonstrate successful operation of the LIFAC process in a retrofit application in a power plant burning high sulfur U.S. coals.

C Produce a dry solid waste suitable for disposal in a landfill.

The test program at Whitewater Valley Station showed that the LIFAC system can be used on flue gas from a typical boiler burning medium sulfur coals with a sulfur content ranging from 2.0 to 2.8 percent. $\mathrm{SO}_{2}$ removal efficiency was 70 percent with a calcium/sulfur $(\mathrm{Ca} / \mathrm{S})$ molar ratio of 2.0, an approach-to-saturation temperature of $10 \mathrm{EF}$, and a limestone fineness of 80 
percent $<325$ mesh. Extrapolation of the test data indicates that the target $\mathrm{SO}_{2}$ removal efficiency of 85 percent can be achieved with the appropriate selection of operating variables.

\section{II.D Environmental Performance}

The demonstration project had a beneficial impact on the environment, reducing $\mathrm{SO}_{2}$ emissions by at least 70 percent. Other emissions, including particulates in the stack gas and solids in the water effluent, met state and local requirements as specified in the environmental monitoring plan. The ash by-product does not require additional treatment before being disposed of in a landfill.

Two areas of potential concern were uncovered. Arsenic in the ash, derived from the feed coal, while at acceptable levels, could become a problem if more stringent regulations are imposed in the future. In addition, methylene chloride was found in the ash. Although there is no regulatory limit for methylene chloride at present, it could become an issue in the future. The LIFAC final report states that the source of this compound is unknown.

\section{II.E Post-Demonstration Achievements}

There has been no additional work on developing or commercializing the LIFAC process since completion of the demonstration project. The LIFAC equipment is not presently being used at the Whitewater Valley Station. $\mathrm{SO}_{2}$ emissions limits at that plant are being met using lower sulfur coal. Worldwide, a total of nine full-scale LIFAC units are in operation, in Canada, China, Finland, and Russia. 


\section{Operating Capabilities Demonstrated}

\section{III.A Size of Unit Demonstrated}

The demonstration project was conducted at RP\&L's Whitewater Valley Station Unit 2, rated at $65 \mathrm{MWe}$ gross (60 MWe net) and firing Indiana bituminous coals having sulfur contents of 2.0 to 2.8 percent. The first major full-scale test of the LIFAC process was performed in Finland in 1986 on a 70-MWe sidestream from a 250-MWe boiler burning 1.5-percent sulfur coal. A second LIFAC reactor was constructed to handle an additional 125-MWe sidestream. The Whitewater Valley CCT project was the first commercial scale application of the LIFAC process at a typical coal-fired boiler in the United States.

Whitewater Valley Unit 2, which began service in 1971, is a tangentially fired boiler, one of the smallest existing boilers of this type in the United States. As such, it has a high temperature profile, which requires injecting the limestone sorbent relatively high in the boiler where the appropriate reaction temperature exists. As a result, only a very short residence time for $\mathrm{SO}_{2}$ sorption is provided. This challenge for the LIFAC system was one of the reasons that Whitewater Valley Unit 2 was chosen for the test program.

In 1980, the unit was fitted with a low- $\mathrm{NO}_{\mathrm{x}}$ concentric firing system for $\mathrm{NO}_{\mathrm{x}}$ control. The ESP is a Lodge Cottrell unit with a specific collection area (SCA) of $198 \mathrm{ft}^{3} / 1,000 \mathrm{acfm}$ of flue gas, which is relatively low compared to typical power plant installations. An average composition of the coals burned in the demonstration project is given in Table 1.

Table 1. Typical Coal Properties

\begin{tabular}{||c|c||}
\hline \hline Coal Source & Indiana Bituminous \\
\hline \multicolumn{2}{||}{ Proximate Analysis, wt\% (as received) } \\
\hline Fixed Carbon & 44.12 \\
\hline Volatile Matter & 33.36 \\
\hline Moisture & 11.74 \\
\hline Ash & 10.78 \\
\hline Total & 100.00 \\
\hline Sulfur, wt\% & 2.24 \\
\hline Higher Heating Value \\
\hline Btu/lb & 11,345 \\
\hline MJ/kg & 25.5 \\
\hline
\end{tabular}




\section{III.B Performance Level Demonstrated}

In long-term testing, the LIFAC demonstration unit achieved 70 percent $\mathrm{SO}_{2}$ emissions reduction at a $\mathrm{Ca} / \mathrm{S}$ molar ratio of 2.0, with an approach-to-saturation temperature of about $10 \mathrm{EF}$ and a limestone fineness of 80 percent $<325$ mesh. Increasing the recycle rate and sustaining a $5 \mathrm{EF}$ approach-to-saturation temperature at a $\mathrm{Ca} / \mathrm{S}$ ratio of 2.0 was projected to be capable of increasing $\mathrm{SO}_{2}$ removal efficiency to 85 percent. The significance of these variables is discussed in the following section.

\section{III.C Major Operating and Design Variables Studied}

A number of parametric studies were performed to determine the effects of variables on $\mathrm{SO}_{2}$ removal. The major parameters studied are shown in Table 2, and the results are summarized following the table.

Table 2. Process Parameters and Ranges

\begin{tabular}{|c|c|c|}
\hline Process Parameter & Unit of Measure & Test Range \\
\hline \hline Coal quality & Wt\% S (as received) & $2.0-2.8$ \\
\hline Limestone grind & Mesh & $\begin{array}{l}85 \%<325 \\
85 \%<200\end{array}$ \\
\hline Boiler load & MWe & $43-60$ \\
\hline Ca/S ratio & Mol/mol & $1.0-2.8$ \\
\hline $\begin{array}{c}\text { Reactor outlet } \\
\text { temperature }\end{array}$ & FF above saturation & $4-11$ \\
\hline $\begin{array}{c}\text { Ash recycle ratio } \\
\text { lb/lb }\end{array}$ & $0.0-1.0$ \\
\hline
\end{tabular}

At a given $\mathrm{Ca} / \mathrm{S}$ molar ratio, $\mathrm{SO}_{2}$ removal efficiency is significantly higher for a fine limestone grind (80 percent $<325$ mesh) than for a coarser limestone grind ( 80 percent $<200$ mesh). This difference ranges from less than 10 to over 20 percentage points. These data are shown graphically in Figure 3. This result is not unexpected, since the finer grind has a higher surface area per unit weight and hence is likely to be more reactive. The finer limestone grind is more expensive because of the higher grinding cost. Both of the limestones had a high $\mathrm{CaCO}_{3}$ content, ranging from 90 to 95 percent. 


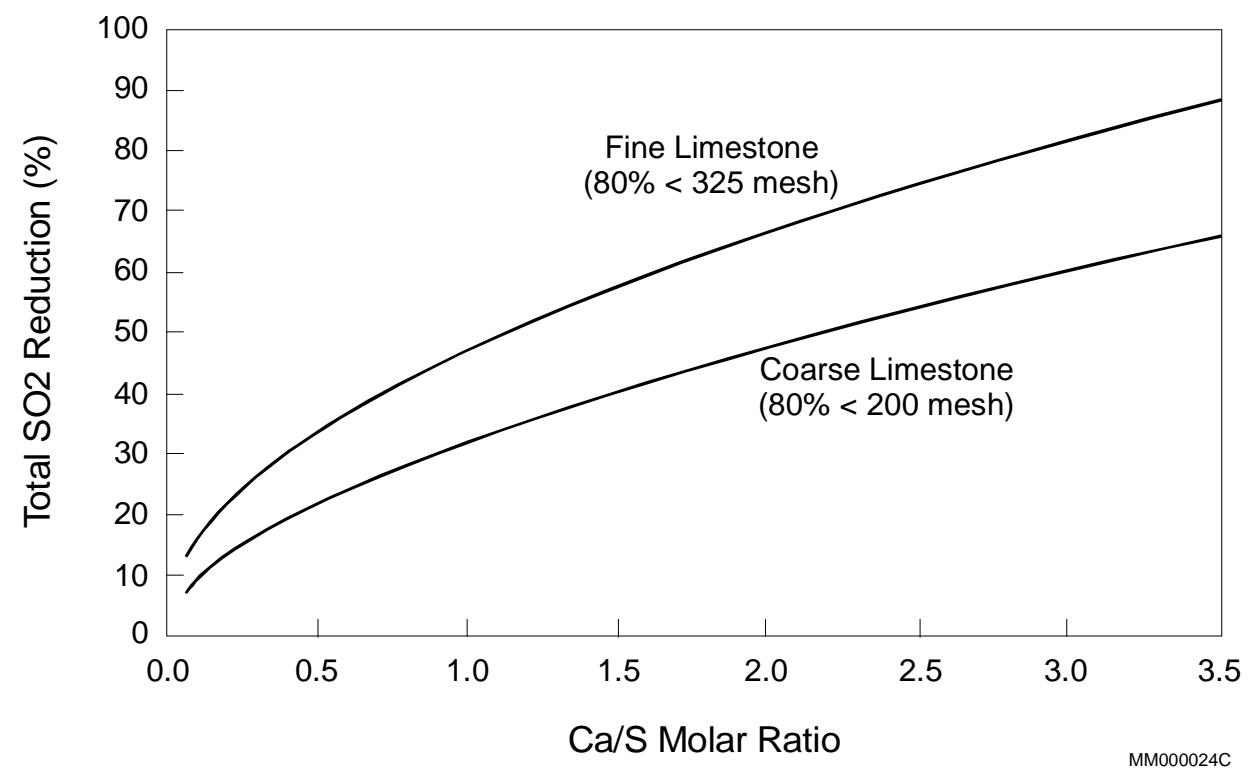

Figure 3. Effect of Limestone Grind Size on $\mathrm{SO}_{2}$ Removal

In another series of parametric tests, $\mathrm{SO}_{2}$ removal efficiency was shown to increase linearly from about 60 percent at a $1.5 \mathrm{Ca} / \mathrm{S}$ ratio to about 80 percent at a $2.8 \mathrm{Ca} / \mathrm{S}$ ratio. The increase in $\mathrm{SO}_{2}$ removal is at the expense of sorbent consumption, which has a significant effect on the economics. Normal operation in long-term testing was at a $\mathrm{Ca} / \mathrm{S}$ ratio of 2.0. The effect of the $\mathrm{Ca} / \mathrm{S}$ ratio is shown in Figure 4.

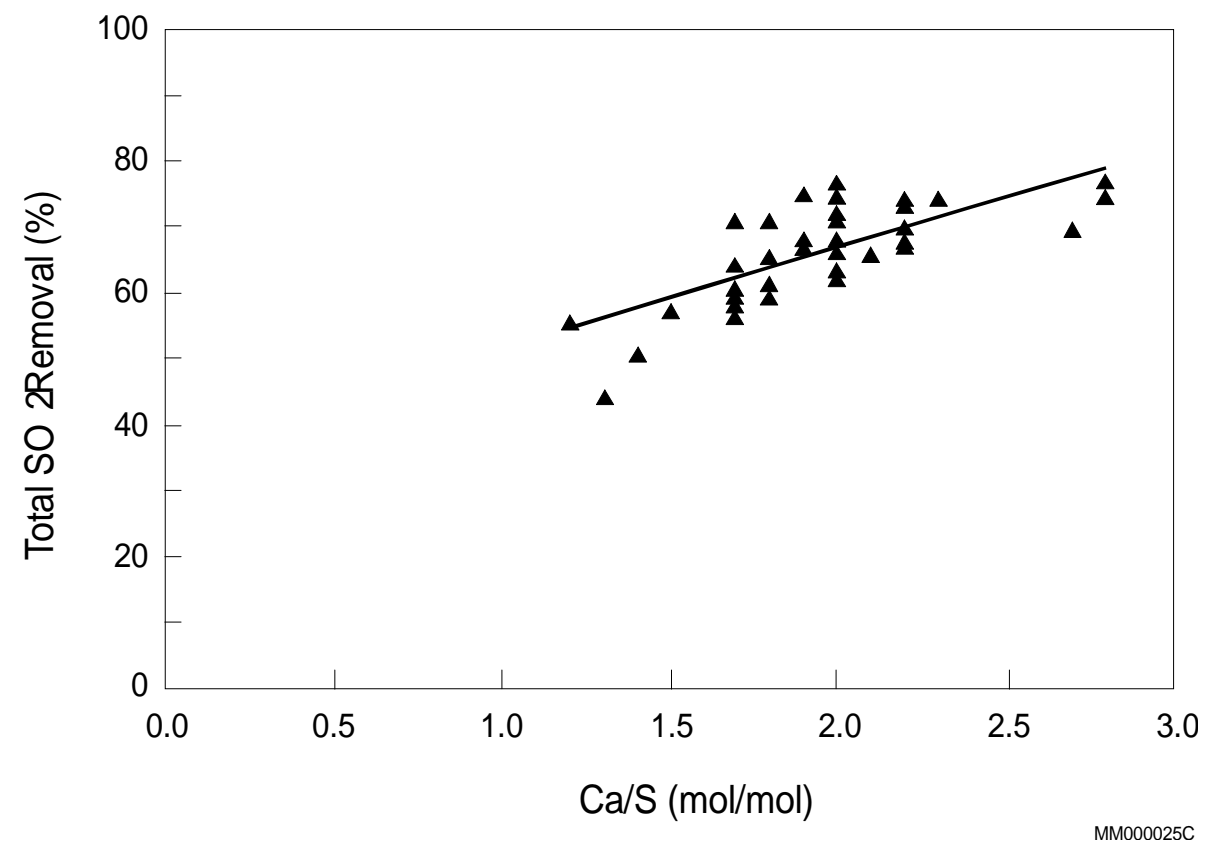

Figure 4. Effect of $\mathrm{Ca} / \mathrm{S}$ Ratio on $\mathrm{SO}_{2}$ Removal 
The reactor outlet temperature must be kept at least several degrees above the flue gas saturation temperature of about $126 \mathrm{EF}$. Otherwise, the moisture content of the reactor bottom ash is too high for the ash handling system, which is designed to transport only dry ash. In addition, condensation of acid gases leads to severe downstream corrosion. However, $\mathrm{SO}_{2}$ removal efficiency improves as the reactor bottom temperature approaches the flue gas saturation temperature. The challenge is to operate at the optimum temperature which maximizes $\mathrm{SO}_{2}$ removal while minimizing potential problems.

As shown in Figure 5, $\mathrm{SO}_{2}$ removal increases from an average of about 60 percent at a temperature approach above saturation of $11 \mathrm{EF}$ to about 70 percent at $4 \mathrm{EF}$. The normal operating value was $10 \mathrm{EF}$, but the parametric studies demonstrated the feasibility of operating at the lower approach temperatures, with corresponding improvement in process efficiency.

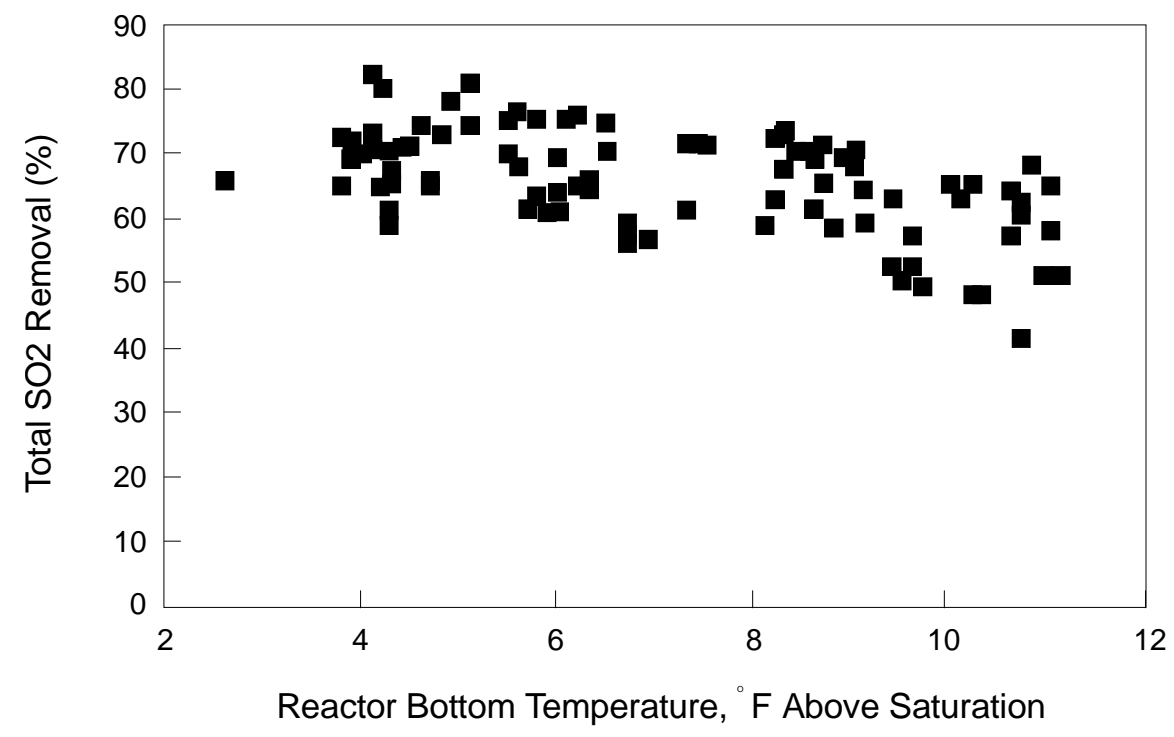

Figure 5. Effect of Approach-to-Saturation Temperature on $\mathrm{SO}_{2}$ Removal

To achieve improved process performance, fly ash containing unreacted sorbent was recycled from the ESP hoppers to the activation reactor inlet duct. Because of equipment limitations, it was not feasible to explore the full range of recycle rates in the demonstration test runs. However, in a series of parametric tests it was found that overall $\mathrm{SO}_{2}$ removal efficiency increases from about 50 percent at a recycle ratio of 20 percent to about 70 percent at a recycle ratio of 100 percent. This effect is shown in Figure 6. The LIFAC final report does not clarify what the recycle ratio was at the conditions for maximum $\mathrm{SO}_{2}$ removal.

$\mathrm{SO}_{2}$ removal performance was essentially constant over a range of boiler loads from 43 to 60 MWe. This effect is shown in Figure 7. 


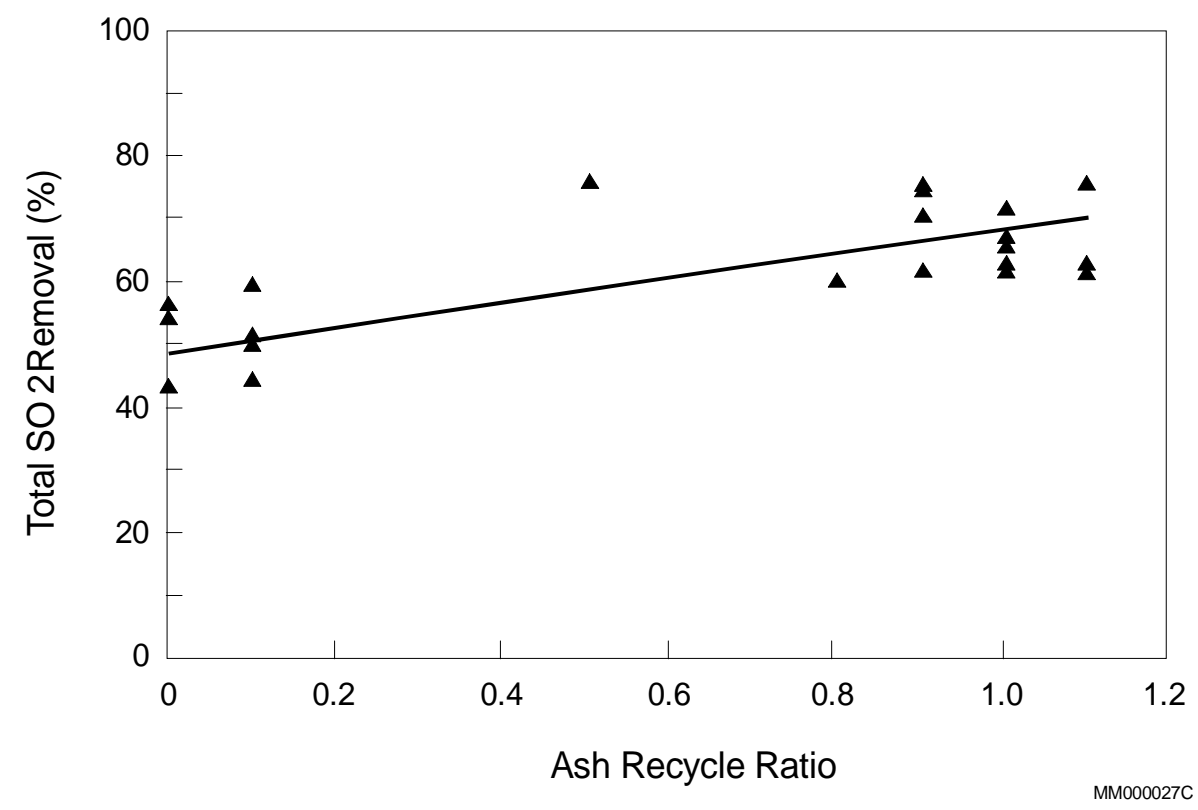

Figure 6. Effect of Ash Recycle Ratio on $\mathrm{SO}_{2}$ Removal

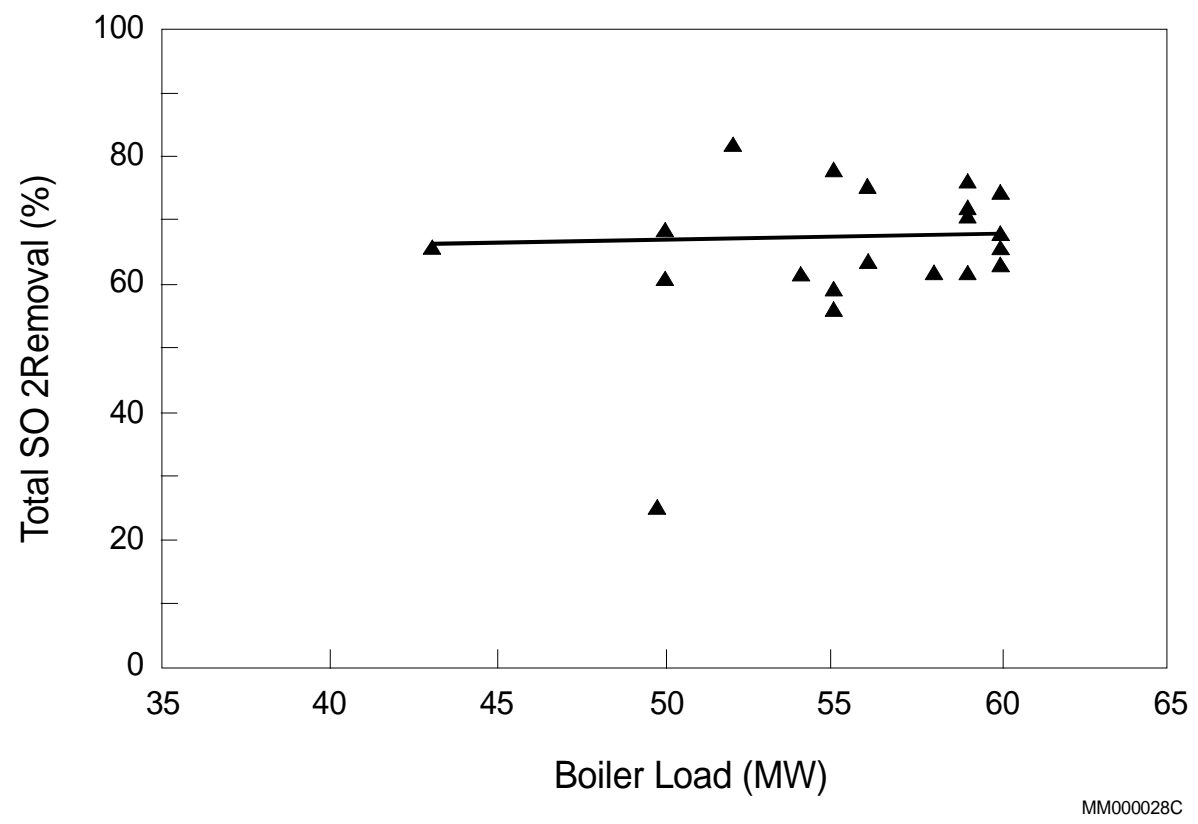

Figure 7. Effect of Boiler Load on $\mathrm{SO}_{2}$ Removal

It was not feasible to perform a systematic study of the effect of coal sulfur content on process performance because other operating conditions were not sufficiently stable. However, the project demonstrated that the LIFAC process is applicable to coals with sulfur contents that range between 2.0 and 2.8 percent. There is no reason to believe that the process cannot be 
applied to coals having a sulfur content above 3 percent, which would generally be considered to be high sulfur.

\section{III.D Boiler Impacts}

The CCT demonstration project had no significant effect on power plant performance. Boiler operation was essentially unaffected, and ESP particle collection efficiency remained high despite the higher solids loading and the relatively small SCA. Reheating the flue gas prior to its entering the ESP was found to improve ESP performance. When operating with the finer limestone grind, the soot-blowing interval had to be reduced from 6.0 to 4.5 hours to avoid solids deposition on the furnace and superheater tubes. No fouling effects attributed to limestone injection were discovered on the boiler walls, in the economizer, or in the air preheater.

The amount of bottom ash increased, but there was no negative impact on the ash handling system. Some mechanical problems occurred with the process equipment, but they were relatively minor and were corrected during the course of the demonstration project.

\section{III.E Commercialization of the Technology}

LIFAC systems have been designed for plant capacities ranging from 25 to $300 \mathrm{MWe}$. Based on Tampella's experience, the maximum size LIFAC reactor corresponds to a power plant capacity of about 150 MWe. Thus a 300-MWe plant would require two LIFAC reactors. The Whitewater Valley Station demonstration proved the operability and reliability of the LIFAC process when burning typical U.S. bituminous coals. A total of nine commercial LIFAC installations are in other countries, including Canada, China, Finland, and Russia. The LIFAC final report lists these, but provides little detailed data, such as the sulfur content of the coals fired or the $\mathrm{Ca} / \mathrm{S}$ ratio.

Aside from the RP\&L demonstration unit, the LIFAC process has not been placed in commercial operation in the United States. This may relate to the current trend in which mandated $\mathrm{SO}_{2}$ emission standards are being met by means other than FGD. Relatively few of the power plants regulated under the 1990 Clean Air Act Amendments (CAAA) have installed scrubbers for $\mathrm{SO}_{2}$ control. A large proportion of these plants have achieved compliance by fuel switching or by purchasing $\mathrm{SO}_{2}$ emission credits. 


\section{Market Analysis}

\section{IV.A Potential Markets}

The LIFAC process can be used for retrofitting existing boilers or installing new boilers, and is not dependent on boiler type, age, or size, or rank and sulfur content of the coal burned. Whereas conventional wet scrubbers are designed for $\mathrm{SO}_{2}$ removal of 90 percent or more, the LIFAC process achieves more limited removal at a potentially lower cost. Although $\mathrm{SO}_{2}$ emissions standards are becoming increasingly more stringent - requiring at least 90-percent removal when firing most medium- to high-sulfur coals - utilities could choose to over-control some of their power plants and thereby allowing some other plants in the system to operate at lower levels of $\mathrm{SO}_{2}$ removal.

The acid rain provisions of the CAAA give utilities the option of selecting the most costeffective approach to control $\mathrm{SO}_{2}$ emissions to required levels. On this basis, there are a large number of candidate plants in the United States suitable for application of the LIFAC process. An internal marketing study by LIFAC identified about 850 boilers having a capacity of 500 MWe or less that could use the process. LIFAC could obtain a share of the market because of its cost competitiveness in certain applications. However, as indicated above, switching to low sulfur fuels and purchasing $\mathrm{SO}_{2}$ emissions allowances have become widely used strategies in the electric power industry, with the result that few if any FGD units are currently being installed.

Technologies competing with LIFAC are likely to be other sorbent injection processes that also have limited $\mathrm{SO}_{2}$ removal capability compared with conventional wet scrubbing processes. Comparative performance and costs on a site-specific basis will determine process choice.

\section{IV.B Economic Assessment}

\section{LIFAC Costs}

A preliminary economic assessment of the LIFAC process is included in the company's final report (ICF North America 1998). The economic estimate was derived from costs for RP\&L's Whitewater Valley demonstration project as applied to a commercial design. RP\&L's capital cost of $\$ 8.1$ million or $\$ 125 / \mathrm{kW}$ is summarized in Table 3. In addition to the cost of conducting the demonstration, the RP\&L project required special equipment, especially instrumentation for test work, which would not be required for a commercial facility. On the other hand, some process equipment was available on site as a result of an earlier FGD demonstration at that plant and this was donated to the LIFAC test project. 
Table 3. LIFAC Demonstration Capital Cost at Richmond Power \& Light

\begin{tabular}{||c|r|}
\hline Equipment and Materials & \multicolumn{1}{|c|}{ Cost } \\
\hline Limestone Handling and Storage & $\$ 160,000$ \\
\hline Activation Rector and Ductwork & $\$ 669,000$ \\
\hline Sorbent Recycle System & $\$ 67,000$ \\
\hline Electrical/Instrumentation & $\$ 272,000$ \\
\hline I.D. Fan Upgrade & $\$ 255,000$ \\
\hline Total Equipment and Materials & $\mathbf{\$ 1 , 4 2 3 , 0 0 0}$ \\
\hline Subcontracts & \multicolumn{1}{|c|}{ Cost } \\
\hline Foundations & $\$ 324,000$ \\
\hline Reactor Fabrication and Erection & $\$ 1,670,000$ \\
\hline Structural/Mechanical/Piping & $\$ 1,569,000$ \\
\hline Electrical/Instrumentation & $\$ 574,000$ \\
\hline Insulation and Cladding & $\$ 268,000$ \\
\hline Miscellaneous Fabrication & $\$ 573,000$ \\
\hline Total Subcontrcts & $\mathbf{\$ 4 , 9 7 8 , 0 0 0}$ \\
\hline Engineering & $\$ 1,200,000$ \\
\hline Management and Adminstration & $\$ 300,000$ \\
\hline Construction Supervision & $\$ 200,000$ \\
\hline Total Capital Cost & $\mathbf{\$ 8 , 1 0 1 , 0 0 0}$ \\
\hline \hline
\end{tabular}

These factors were taken into account in preparation of a generic cost estimate for a 150MWe LIFAC system for commercial application. The annual operating costs for RP\&L demonstration are reported in Table 4. The fixed operating cost of $\$ 581,200$ was based on two operators per shift, three shifts per day and seven days per week. The variable operating cost is reported as $\$ 327.50 / \mathrm{hr}$, and is based on actual site cost. The estimated costs for commercial applications are reported in Table 5.

Table 4. Estimated Operating Cost of LIFAC at RP \& L

\begin{tabular}{||l|r||}
\hline Fixed Operating Cost & \multicolumn{1}{|c|}{ Cost } \\
\hline Operating Labor* & $\$ 4,999,200$ \\
\hline Maintenance Labor & $\$ 25,000$ \\
\hline Maintenance Material & $\$ 50,000$ \\
\hline Administrative and Support Labor & $\$ 7,000$ \\
\hline Total Fixed Operating Cost & $\mathbf{\$ 5 8 1 , 2 0 0}$ \\
\hline Variable Operating cost $(\$ / \mathrm{hr})$ & \multicolumn{1}{c|}{ Cost } \\
\hline Limestone $(\$ 35 /$ ton $)$ & $\$ 210.00$ \\
\hline Reheat Steam $(\$ 0.003 / \mathrm{lb})$ & $\$ 18.50$ \\
\hline Auxiliary Power $(\$ 0.02 / \mathrm{kWhr})$ & $\$ 7.20$ \\
\hline Ash Removal $(\$ 17 /$ ton) & $\$ 91.80$ \\
\hline Total Variable Operating Cost & $\mathbf{\$ 3 2 7 . 5 0}$ \\
\hline
\end{tabular}

*2 operators per shift; 4.2 shifts per week 


\section{Table 5. Estimated Costs for 150 MWe LIFAC System for Commercial Application}

\begin{tabular}{||l|l|}
\hline Capital Costs $(\$ 85 / \mathrm{kW})$ & $1.5 \mathrm{mills} / \mathrm{kWhr}$ \\
\hline Limestone (\$20/ton) & $1.25 \mathrm{mills} / \mathrm{kWhr}$ \\
\hline Disposal (\$15/ton) & $0.9 \mathrm{mills} / \mathrm{kWhr}$ \\
\hline Other & $0.9 \mathrm{mills} / \mathrm{kWhr}$ \\
\hline Total & $\mathbf{4 . 5 5}$ mills/kWhr \\
\hline $\mathrm{SO}_{2}$ Removed & $2.8 \mathrm{lb} / \mathrm{MMBtu}$ \\
\hline$\$ /$ ton $\mathrm{SO}_{2}$ Removed & $\$ 325$ \\
\hline
\end{tabular}

LIFAC summarizes the costs as follows: with feed coal containing $4.0 \mathrm{lb}$ sulfur per $10^{6}$ Btu and assuming 70-percent $\mathrm{SO}_{2}$ removal, a 150-MWe LIFAC retrofit unit has an estimated capital cost of $\$ 85 / \mathrm{kW}$. The levelized total cost is $4.5 \mathrm{mills} / \mathrm{kWh}$, or $\$ 325 /$ ton of $\mathrm{SO}_{2}$ removed. The LIFAC report does not give the bases for these figures, such as project life, cost of capital, or whether the costs represent constant-dollar or current-dollar calculations.

\section{Comparison With Competition}

LIFAC technology would have to compete with other sorbent injection processes having limited $\mathrm{SO}_{2}$ removal capability. In general, sorbent injection is less expensive than wet-process FGD technologies capable of more complete ( $>90$ percent) $\mathrm{SO}_{2}$ removal. There is insufficient information in the LIFAC final report to make a meaningful economic comparison with other sorbent injection technologies or with wet-process FGD. It is clear that the estimated cost of $\$ 325 /$ ton of $\mathrm{SO}_{2}$ is not competitive with allowances that now are in the neighborhood of $\$ 180 /$ ton. 


\section{Conclusions}

The results of the LIFAC CCT demonstration project are summarized as follows:

C Overall $\mathrm{SO}_{2}$ removal of 70 percent was demonstrated in long-term testing at a $\mathrm{Ca} / \mathrm{S}$ molar ratio of 2.0, an approach-to-saturation temperature of about $10 \mathrm{EF}$, and a limestone fineness of 80 percent $<325$ mesh.

C Extrapolating the performance data indicates that reducing the approach-to-saturation temperature to $5 \mathrm{EF}$ and increasing the ash recycle ratio would result in higher overall $\mathrm{SO}_{2}$ removal, potentially up to the target level of about 85 percent.

C The projected levelized cost for a commercial 150-MWe LIFAC retrofit unit is about $\$ 325 /$ ton of $\mathrm{SO}_{2}$ removed, assuming 70-percent $\mathrm{SO}_{2}$ removal, a $\mathrm{Ca} / \mathrm{S}$ molar ratio of 2.0, and an approach-to-saturation temperature of $10 \mathrm{EF}$ with a limestone fineness of 80 percent $<325$ mesh.

LIFAC technology may find a niche in the marketplace, but is unlikely to do so at present since there is very little activity in installing FGD systems in the United States. 


\section{Abbreviations}

\begin{tabular}{|c|c|}
\hline CAAA & Clean Air Act Amendments (of 1990) \\
\hline $\mathrm{CaCO}_{3}$ & limestone, calcium sulfite \\
\hline $\mathrm{Ca}(\mathrm{OH})_{2}$ & hydrated lime \\
\hline $\mathrm{CaSO}_{4}$ & calcium sulfate \\
\hline $\mathrm{CaO}$ & lime \\
\hline $\mathbf{C C T}$ & clean coal technology \\
\hline DOE & U.S. Department of Energy \\
\hline EPRI & Electric Power Research Institute \\
\hline ESP & electrostatic precipitator \\
\hline FGD & flue gas desulfurization \\
\hline LIFAC & limestone injected into the furnace with activation of untreated calcium oxide \\
\hline POC & proof of concept \\
\hline $\mathbf{R P \& L}$ & Richmond Power and Light Company \\
\hline SCA & specific collection area \\
\hline $\mathrm{SO}_{2}$ & sulfur dioxide \\
\hline $\mathrm{SO}_{3}$ & sulfur trioxide \\
\hline
\end{tabular}




\section{References}

Hervol, J., R. Easler, J. Rose, and J. Viiala, 1992, LIFAC Sorbent Injection for Flue Gas Desulfurization, ICF Kaiser and Tampella, presented First Annual Clean Coal Technology Conference, Cleveland, OH, September 1992.

ICF North America, 1998, LIFAC Demonstration at Richmond Power and Light Whitewater Valley Unit No. 2, Final Report, Volume 1: Public Design, and Volume 2: Project Performance and Economics.

LIFAC North America, Inc., 1990, LIFAC Sorbent Injection Desulfurization Demonstration Project, Comprehensive Report to Congress, Clean Coal Technology Program, proposed by LIFAC North America, Inc., U.S. Department of Energy.

Viiala, J., T. Pokki, J. Hervol, and I. Huffman, 1993, LIFAC Sorbent Injection for Flue Gas Desulfurization, Tampella, ICF Kaiser, and RP\&L, presented at the Second Annual Clean Coal Technology Conference, Atlanta, GA, September 1993.

U.S. Department of Energy, 1996, Clean Coal Today, U.S. Department of Energy, Issue No. 21.

U.S. Department of Energy, 1999, Clean Coal Technology Demonstration Program, Program Update, March 1999.

Viiala, J., J. Hervol, and C. Keating, 1994, Commercialization of the LIFAC Sorbent Injection Process in North America, Tampella and ICF Kaiser, presented at the Third Annual Clean Coal Technology Conference, Chicago, IL, September 1994. 